\title{
Electronic Fraud and Performance of Deposit Money Banks in Nigeria: 2008-2018
}

\author{
Charles Emeka Nwobia ${ }^{1}$, Patrick Anayo Adigwe ${ }^{1}$, Gideon Kasie Ezu ${ }^{1} \&$ John Nonso Okoye ${ }^{1}$ \\ ${ }^{1}$ Department of Banking and Finance, Nnamdi Azikiwe University, Awka, Nigeria \\ Correspondence: Gideon Kasie Ezu, Department of Banking and Finance, Nnamdi Azikiwe University, Awka, \\ Anambra State, Nigeria. E-mail: g.ezu@unizik.edu.ng
}

Received: March 31, 2020

Accepted: April 25, 2020

Online Published: May 17, 2020

doi:10.5539/ijbm.v15n6p126

URL: https://doi.org/10.5539/ijbm.v15n6p126

\begin{abstract}
This research work examined electronic fraud and performance of Deposit Money Banks in Nigeria. It is a truism that Nigerian banks have lost of a lot of profit owing to the nefarious activities of fraudulent people including some unscrupulous elements in the banking industry who connive with fraudsters to perpetrate fraud of different magnitude. To this end, the Central Bank of Nigeria in conjunction with Nigeria Bankers Committee established Nigeria Electronic Fraud Forum (NeFF) with the sole aim of monitoring online banks transactions and reporting any financial regulation infringements. Specifically, the objectives of this research work are to analyse the relationship between ATM fraud and performance of DMBs in Nigeria and to evaluate the relationship between POS fraud and performance of DMBs in Nigeria. The data collected were analyzed using basic descriptive ordinary least square (OLS) and multivariate regression panel data setting with econometric analyses. The results showed negative and insignificant relationship between electronic fraud channels and financial performance variables. The study concluded that there is no significant relationship between electronic fraud and financial performance of Deposit Money Banks in Nigeria in the period of study. The study recommended improved collaborations between DMBs, CBN and other stake holders via NeFF to tackle fraud.
\end{abstract}

Keywords: bank capitalization, e-commerce, fraud

\section{Introduction}

The importance of banking sector in every economy cannot be over-emphasized and that is the reason why banks are the most regulated institutions in the whole world. It directs the economy of nations and ensures stability. Due to constant reforms of the banking sector, it has generally metamorphosed in terms of adequate service delivery especially in the areas of electronic payments to customers or on behalf of customers, which was very different from the previous banking practice, which laid a lot of emphasis on the use of cheques, over-drafts etc as a mode of payment to customers.

Tijani and Ilugbemi (2015) stressed that electronic banking has brought unlimited banking opportunities into the banking system. The emergence of technology-driven payment systems has encouraged flexibility and convenience for bank's customers and other stakeholders (Kelvin, 2012). Currently, transactions between buyers and sellers are not necessarily carried out through raw cash, but done through Web based banking (internet) and e-payment products. The flexibility the e-banking systems have afforded its customers accounted for the explosion in payment and collection in the banking system.

The increase in e-payment activities has attracted unprecedented high level of electronic fraud in the banking system all over the world and Nigeria in particular. Electronic fraud is a big impediment to the success and stability of the payment and collection systems and has led to the distress of many banks. According to Rezaee (2004), electronic fraud is still on the rise, despite the unprecedented measure to minimize the incidence of electronic fraud, because the fraudsters continually devices new strategic ways of committing electronic fraud. The most contradicting factor however is that, considering the enormous harm which electronic fraud has done to the economy, the process of conviction and punishment is relatively weak. This has emboldened the perpetrators to continue with their nefarious activities (Cain, 1999).

The alarming rate of fraud across the globe has caused serious setbacks to banking activities. For instance, in the first quarter of 2014 alone 381 reported breaches led to the exposure of 10,879,401 individual records of fraud in 
the United States of America. Another major electronic fraud was the World Cup-related cyber security concerns in Brazil. Electronic fraud caused 95\% of losses for Brazilian banks in 2014. The Republic of South Africa uncovered a fraud campaign with a potential loss of US\$3.75 billion through the country's most popular payment mechanism - the Boleto Bancario, which is similar to the money order payment in the United States (Vinton, 2014).

In Nigeria, the disturbing trend of increase in electronic fraud (e-fraud) across major sectors of the Nigerian economy is alarming. The incidence of electronic fraud which resulted in massive acceptance of new mode of mobile money and electronic banking and payment systems has been discovered to cost Nigeria a huge sum of money annually (Osuagwu \& Umeh, 2018). Nigeria Electronic Fraud Forum (NeFF) in its annual report for 2018, reported electronic fraud of N5.571 Billion between 2015 and 2017.Most of these electronic frauds are achieved via hacking of banks customer account and data base, and these have been targeted both locally and internationally, thus precipitating losses in billions of naira. The Central Bank of Nigeria (CBN) classifies e-fraud as the highest risk in the banking sector which involves different e-payment classifications, which in itself have encountered hacking by electronic fraudsters. No doubt, electronic fraud has affected the performance of the Nigerian deposit money banks. The growth experienced from the possible enhancement of the electronic banking and its juicy services that has continued to facilitate ease of monetary transactions among customers is however challenged by the continuous presence and threat of electronic fraud. This study intends to ascertain how electronic fraud has affected the performance of deposit money banks (DMB) in Nigeria.

\subsection{Statement of the Problem}

The decisions of economies of the world to tilt towards cashless economy have prompted central banks of nations to incorporate and enforce electronic banking into the commercial activities of deposit money banks across the world and Nigeria in particular. However, developing countries and emerging economies are steadily migrating from raw cash to a cashless economy owing to speedy implementation of cashless policy by various central banks, (Enoch, John \& Olumuyiwa, 2013). Electronic fraud is a threat to every channel of electronic business. Fraud can be likened to a highly contagious disease that speedily and negatively affects the growth of banking sector, which is felt in the whole economy. According to Gitau and Samson (2016), electronic fraud has forced the liquidity of banks to plummet and their performance to wane. The Speed at which electronic fraud is escalating is alarming and the means of reduction have not been encouraging. This has amounted to gross degeneration in the productivity/performance of the deposit money banks in Nigeria. According to Neff annual report 2018, ATM fraud alone amounted to N268, 866,920.00 for 2014. ATM fraud increased in 2015 and 2016 to N355, 892,203.00 and N464, 514,684.00 respectively. The loss as also shown by the report for E-commerce for 2014 to 2016 showed increasing trend to the tune of N58,994,920.00, N52,161,394.00 and N132,252,118.00 for 2014,2015 and 2016 respectively.

E-fraud and bank performance being a relatively a new area, has not witnessed much studies and there are controversy surrounding their findings. The studies of Andulrashed, Babaitu and Yinusa (2012), Kam and Okorafor (2013), Akindele (2011) agreed that there is a positive relationship between electronic fraud and performance of deposit money banks in Nigeria. There is a contradicting view by Inaya and Isito (2016), that, there is a negative relationship between electronic fraud and deposit money banks in Nigeria. The study by Nwankwo (2013) on the implication of fraud on commercial banks performance in Nigeria did not focus on electronic fraud, which is a component of total fraud. All the studies with their varying findings did not fully address the implication of financial loss caused by electronic fraud on banks performance in Nigeria and did not consider the impact or weight of various channels or tools of electronic fraud on bank performance. Hence this study intends to determine the effect of financial losses caused by electronic fraud on bank performance in Nigeria looking basically at four electronic service channels: ATM, POS, E-commerce and Mobile banking on return on assets (ROA) of Deposit Money Banks in Nigeria.

\subsection{Objectives of the Study}

The broad objective of this study is to determine the effect of electronic fraud on the performance of Deposit Money Banks in Nigeria. The specific objectives of the study are:

1. To examine the effect of ATM fraud on the performance of Deposit Money Banks in Nigeria.

2. To evaluate the effect of POS fraud on the performance of Deposit Money Banks in Nigeria.

\section{Review of Related Literature}

\subsection{Conceptual Review}

Agu (1985) states that in measuring profits and profitability of the Nigeria Banking System 'using return on assets 
(ROA), return on equity (ROE) and the average consumer price index finds that financial health of banks and consequently their performance are dependent on profits declared and that the ability of banks to control and reduce operating cost will greatly determine the amounts of profits to be declared. He however could not statistically determine the relationship between profits and operating cost.

According to Ovia (2001) electronic banking is a product of e-commerce in the field of banking and financial services. The electronic payment system otherwise called E-Payment involves cash substitutes such as direct debits/credits, debit cards, internet banking, credit cards, electronic funds transfer, and e-payments systems to complete transactions. From the various analyses of definition of E-banking, it can be deduced that any banking transactions that is devoid of the use of raw cash can be termed E-banking. It is faster and more accurate.

Electronic banking is the use of electronic and telecommunication networks to deliver a wide range of value-added products and services to bank customers (Steven, 2002).

Another name for electronic banking is electronic funds transfer (EFT). It involves the use of electronic means in fund transfers. It can be from one account to another, rather than through manual means, which involves cheque or cash. It can therefore be defined as the process by which a bank customer initiates banking transaction via electronic device without visiting the brick and mortar institution. At world level, information communication technology advancement has greatly contributed to economic growth including banking and finance. The internet is one of the fastest- growing areas of software development. Due to the crucial roles of financial institutions in the growth and economic development of any nation, it has become pertinent to protect these institutions from the pranks and vagaries of fraudsters. The increased use of ICT such as computers, mobile phones, internet and other associated technologies are the routes which gave rise to lot of constructive and destructive work.

It was seriously argued that there is not sufficient legislation to enable the eradication of cyber crime entirely thereby forcing businesses and banks to suffer losses from credit card fraud which contnue to increase geometrically. In an attempt to make best use of the advantages of technology utilization, most people end up becoming victims. Cyber fraudsters imitate original websites where victims divulge personal information such as usernames, passwords and credit card details. At times, emails are forwarded to unsuspecting individuals requesting for disclosure and/or verification of sensitive information, and upon disclosure of such information the offenders regrettably make online transfers.

The return on capital employed (ROC)/ shareholders funds is a measure of efficiency of management in the application or use of the organization's available funds or resources in a given financial period. For this purpose, capital employed is taken as shareholders fund which is made up of equity and all reserves. It is measured by comparing the profit made by the company with the capital used in making the profit and set as a percentage or fraction (Egungwu, 2005). Enyi (2007) maintains that a firm's internal performance determines it external position in the stock exchange bearing the economic force of demand and supply of its stocks, which invariably is influenced by the firm's performance. Performance indication can only be meaningful to the user if it bears a true reflection of the relationship that it has intended to test.

\subsubsection{Adequacy of Bank Capital and Financial Performance}

Capital adequacy is relevant for the stability of any banking system as it serves as financial system confidence booster and helps in mobilization of savings for growth and development. The capital requirement for operation of banks are subject to regulation by a country's apex banks, and such results in competition in the banking sector in an attempt to meet up with requirement. In Nigeria, the latest issue in capital requirement was increasing the minimum capital of banks from N2 billion to N25 billion in 2004 reflecting about 1, 150\% upsurge in bank's minimum capital requirement in Nigeria. This saw a reduction in the number of deposit money banks to twenty five (25) from eighty nine (89) as a result of mergers and acquisition coupled with revocation of license of some banks that failed to comply with the capital base adjustment. Since bank's capital accounts for over $30 \%$ and $44 \%$ of the bank's total assets and deposited respectively, determining capital adequacy of banks in isolation (without considering its performance) might be misleading (Osigwe, 2016).

\subsection{Theoretical Framework}

The theory of this research work is anchored on Alexis theory of asymmetric fraud of 2001. The theory maintained that fraud perpetration is dynamic due to the changing nature of information communication technology. The perpetrators always devise many ways of outsmarting unsuspecting public owing to their nefarious ingenuity. The theory maintained that there is a significant relationship between electronic fraud and profitability of firms. If banks did not fortify their software against hackers, the possibility of hacking into it and causing unimaginable havoc to their profit and corporate existence is very high. Fraudsters equally use the website of banks to dupe 
individuals and corporate organizations. The lower the fraud experienced by a bank, the higher the profit declares.

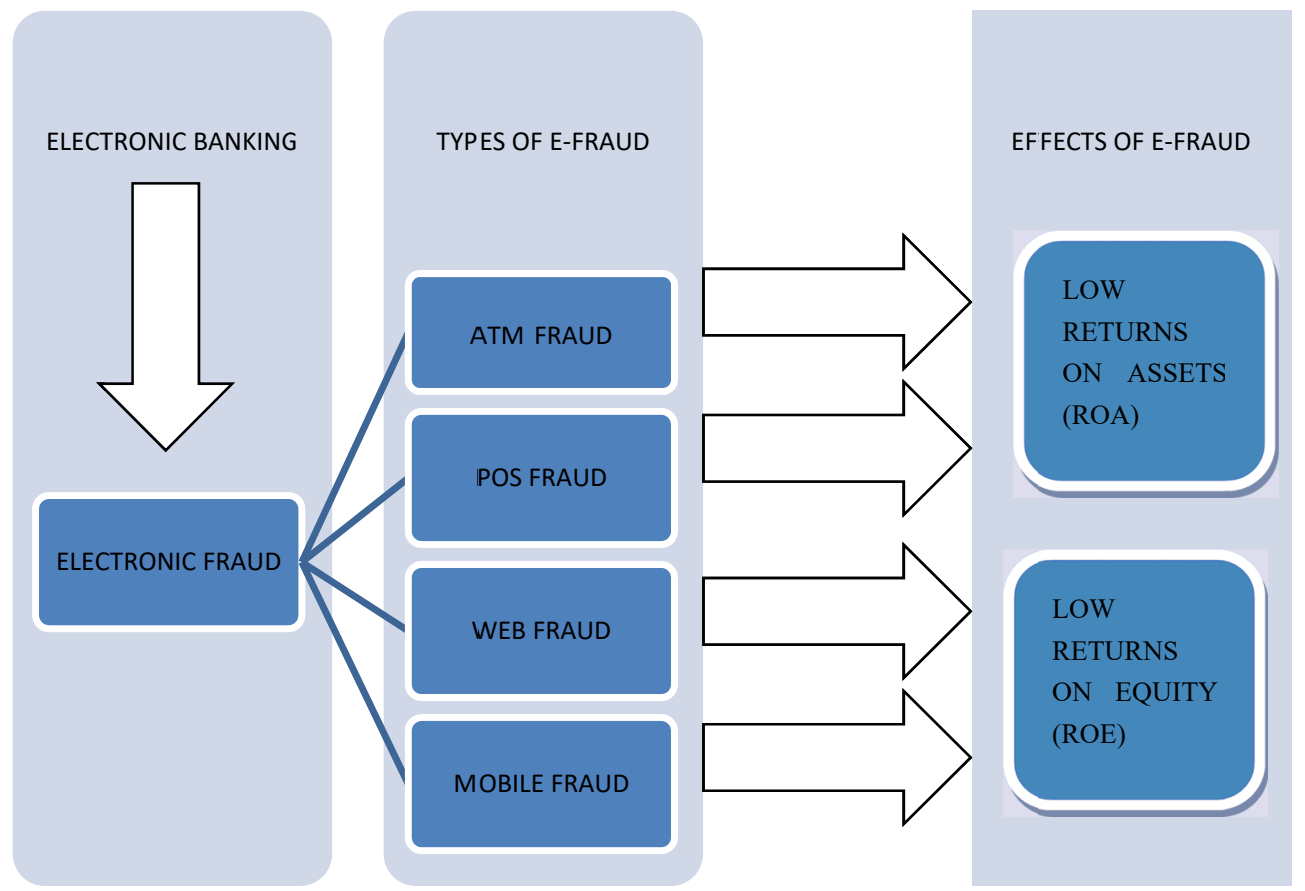

Figure 1. Fraud theory (Alexis, 2001)

\subsection{Empirical Review}

Ekudo (2013) evaluated the relationship between commercial banks performance and fraud in Nigeria. The research observed that the most common types of fraud perpetrated by fraudsters are ATM Fraud, cheque forgery, fund transfers and phishing. Augmented Dickey Fuller (ADF), unit root test and co-integration test using ordinary least square was used for analysis. The outcome of the research showed that there is a significant impact of fraud on commercial banks' performance in Nigeria. The implication of this research work is that if e-fraud is not reduced to its barest minimum, it will impact negatively on the overall growth Nigeria banks thereby sowing the economy since banks are sine-qua-non to the growth of any economy.

Mwabu (2013) determine the factors influencing electronic fraud in the banking industry in Kenya with reference to Kenya Commercial Bank (Central Region). This study employed descriptive survey design. The posulation is drawn from all staff of Kenya Commercial Bank central region which are 630 but narrowed to 241 staff members using stratified random sampling technique in selecting the staff members based on their department and their management level. Kenya Central Bank (KCB) Kenya Central region had 37 branches and a total of 630 staff members as at time of the study. The study based on primary data was collected using questionnaires and subjected to multi-linear regression model. The study found that level of awareness of the customer had the greatest effect on the electronic fraud in the banking industry, followed by security controls, then quality management while level of salaries and remuneration had the least effect to the electronic fraud in the banking industry. The research is considered standard, considering the period in which the study was carried out and non availability of secondary data from the apex banking institution in Kenya. The sample size used has a good representation of the population and tool of analysis adequate.

Afzal, Redvin and Jamaliah (2017) investigated the factors that contribute towards online purchases from the experience of online fraud victims. The qualitative study analyses experience of online fraud victims in order to gain insight to individual behaviour and determine the reason why they are induced in making the online purchase. The samples used in this study are the online fraud victims of E-commerce. In addition to administration of questionnaire, seven phone interviews of online fraud victims were held in data gathering. The survey design employed psychographic approach to measure subjective information and used NVIVO software for regression analysis. The study concludes that people with higher levels of familiarity, confidence and trust seems to have higher levels of trustworthiness to e-commerce. 


\section{Research Methodology}

Ex post facto research design will be used for this study due its appropriateness in data gathering especially in conducting research as regards business and social sciences. It is mostly used where data have been gathered by dependable authorities and will be difficult to manipulate. To this end, the major reasons for choosing ex post facto research design is that the data is secondary and the variable chosen cannot be easily manipulated.

\subsection{Model Specification and Validity}

The functional relationship between dependent and the independent variables used in this study are established as follows.

\section{Model I:}

$$
\begin{gathered}
\mathrm{ROA}=\mathrm{f}(\mathrm{ATM}) \\
\mathrm{ROA}=\mathrm{a}_{0}+\mathrm{a}_{1} \mathrm{ATM}+\mathrm{u} \\
\mu=\text { Error } \text { term } \\
\text { ao }=\text { Intercept } \\
a_{1}=\text { parameter } / \text { coefficient }
\end{gathered}
$$

Model II:

$$
\begin{gathered}
\mathrm{ROA}=\mathrm{f}(\mathrm{POS}) \\
\mathrm{ROA}=\mathrm{a}_{0}+\mathrm{a}_{1} \mathrm{POS}+\mathrm{u} \\
\mu=\text { Error term } \\
\text { ao }=\text { Intercept } \\
a_{1}=\text { parameter } / \text { coefficient }
\end{gathered}
$$

Where ROA $=$ Return on Assets

ATM $=$ Automated Teller Machine fraud

POS $=$ Point of Sale Terminal fraud

$\mathrm{a}_{0}, \mathrm{a}_{1}, \mathrm{a}_{2}$ and $\mathrm{a}_{3}$ - are parameters

$\mathrm{U}_{\mathrm{t}}=$ Error term

\subsection{Statement of Hypotheses}

The research hypotheses are stated in null form as follows;

$\mathrm{Ho}_{1}$ : ATM fraud does not significantly affect the performance of deposit money banks in Nigeria.

$\mathrm{Ho}_{2}$ : POS fraud does not significantly affect the performance of deposit money banks in Nigeria. 


\section{Data Presentation and Analysis}

Table 1. ATM Fraud, POS fraud and return on assets of deposit money banks from 2008 to 2018

\begin{tabular}{llll}
\hline YEAR & $\begin{array}{l}\text { ATM FRAUD (billions ) } \\
\text { Naira }\end{array}$ & $\begin{array}{l}\text { POS } \\
\text { (billions ) Naira }\end{array}$ & $\begin{array}{l}\text { FRAUD } \\
\text { ROA \% }\end{array}$ \\
\hline 2008 & 0 & 0 & 4.29 \\
2009 & 0 & 0 & -9.28 \\
2010 & 0 & 0 & 3.91 \\
2011 & 0 & 0 & -0.04 \\
2012 & 0 & 0 & 2.62 \\
2013 & $54,999,829$ & $5,851,443$ & 2.32 \\
2014 & $268,866,929$ & $157,610,831$ & 3.39 \\
2015 & $355,892,203$ & $63,533,467$ & 2.34 \\
2016 & $464,514,684$ & $243,321,812$ & 1.48 \\
2017 & $497,643,654$ & $79,444,442$ & 0.48 \\
2018 & $497,124,413.80$ & $390,972,199.40$ & 0.88 \\
\hline
\end{tabular}

Source: NIBSS Publication 2018 and NDIC Annual report.

\subsection{Data Descriptive Features}

The descriptive features of the data were structured to capture the mean, median, maximum, standard deviation, skewness, kurtosis, Jarque-Bera, p-value and number of observations of the data set.

Table 2. Data descriptive features

\begin{tabular}{cccc}
\hline & ATM & POS & ROA \\
\hline Mean & $1.94 \mathrm{E}+08$ & 85521290 & 1.126364 \\
Median & 54999829 & 5851443. & 2.320000 \\
Maximum & $4.98 \mathrm{E}+08$ & $3.91 \mathrm{E}+08$ & 4.290000 \\
Minimum & 0.000000 & 0.000000 & -9.280000 \\
Std. Dev. & $2.23 \mathrm{E}+08$ & $1.29 \mathrm{E}+08$ & 3.718417 \\
Skewness & 0.383210 & 1.419163 & -2.156454 \\
Kurtosis & 1.356016 & 3.817629 & 6.861456 \\
Jarque-Bera & 1.507955 & 3.998779 & 15.35968 \\
Probability & 0.470491 & 0.135418 & 0.000462 \\
Sum & $2.14 \mathrm{E}+09$ & $9.41 \mathrm{E}+08$ & 12.39000 \\
Sum Sq. Dev. & $4.97 \mathrm{E}+17$ & $1.67 \mathrm{E}+17$ & 138.2663 \\
Observations & 11 & 11 & 11 \\
\hline
\end{tabular}

Source: E-views 9.0 version data output.

From the descriptive features of the data common sample in Table 2, mean were shown to be 1.94E+08 for ATM, 85521290 for POS and 1.126364 for ROA. The median for the sample data are 54999829, 5851443 and 2.320000 respectively for ATM, POS and ROA. The maximum and minimum values are 4.98E+08 and 0.000000 for ATM, $3.91 \mathrm{E}+08$ and 0.000000 for POS, 4.290000 and -9.280000 for ROA. The standard deviations are 2.23E +08 , 1.29E+08, and 3.718417 for ATM, POS and ROA.

The variables of standard deviations were found to be positively skewed towards normality as evidenced by the positive values of the skewness statistic except for ROA. The Jarque-Bera suggests that all the variables are normally distributed as the p-values of these variables (ATM and POS) are in excess of the 5\% level of significance except ROA which will be tolerated as it's still consistent with the behavour of most economic and financial time series.

\subsection{Test for Unit Root}

$\mathrm{H}_{0}$ : data is not stationary 
$\mathrm{H}_{1}$ : data is stationary

The Augmented Dickey-Fuller (ADF) and Phillips Perron (PP) test of unit root were used to prove that the data were stationary.

Table 3. Result of ADF unit root test at level

\begin{tabular}{|c|c|c|c|c|c|c|c|}
\hline Variables & $\begin{array}{l}\text { Adf Test } \\
\text { Statistics } \\
\text { Value }\end{array}$ & $\begin{array}{l}\text { Mackinnon } \\
\text { Value At 5\% }\end{array}$ & Critical & $\begin{array}{l}\text { Order Of } \\
\text { Integration }\end{array}$ & Decision Rule & & Remarks \\
\hline ATM & 1.366095 & -1.982344 & & $\mathrm{I}(0)$ & Accept & Reject & Non-Stationary \\
\hline POS & -1.131751 & -3.212696 & & $\mathrm{I}(0)$ & Accept & Reject & Non-Stationary \\
\hline ROA & -4.705331 & -3.212696 & & $\mathrm{I}(0)$ & Reject & Accept & Stationary \\
\hline
\end{tabular}

Source: Author's Computation.

From table3, the results of the test for stationarity of data at level i.e. before differencing, it could be deduced that all the variables have their ADF test statistics value lesser than the Mackinnon critical value (at absolute term) and at $5 \%$ except ROA. Therefore, we fail to reject $\mathrm{H}_{0}$ and there is sufficient evidence to support $\mathrm{H}_{1}$ for ATM and POS.

To ensure the stationarity of data for variables found to be non-stationary at level, there is need to proceed to test for stationarity at first difference. The first difference ADF unit root test is presented in table 4.3.2

Table 4. Result of ADF unit root test at first difference

\begin{tabular}{lllllll}
\hline Variables & $\begin{array}{l}\text { Adf Test } \\
\text { Statistics } \\
\text { Value }\end{array}$ & $\begin{array}{l}\text { Mackinnon } \\
\text { Value At } 5 \%\end{array}$ & $\begin{array}{c}\text { Critical } \\
\text { Integration }\end{array}$ & $\begin{array}{l}\text { Order } \\
\text { Of }\end{array}$ & Decision Rule & Remarks \\
\hline ATM & -1.354296 & -1.988198 & $\mathrm{I}(1)$ & Accept & Reject & Non-Stationary \\
POS & -11.02036 & -3.259808 & $\mathrm{I}(1)$ & Reject & Accept & Stationary \\
ROA & -13.05085 & -3.259808 & $\mathrm{I}(1)$ & Reject & Accept & Stationary \\
\hline
\end{tabular}

Source: Author's Computation.

From table 4 the results of the test for stationarity of data at level i.e. before differencing, it could be deduced that ATM and MOBILE have their ADF test statistics value lesser than the Mackinnon critical value (at absolute term) and at 5\% except for POS and ROA. Therefore, we fail to reject $\mathrm{H}_{0}$ and there is sufficient evidence to support $\mathrm{H}_{1}$ for ATM.

To ensure the stationarity of data for variables found to be non-stationary at first difference, there is need to proceed to test for stationarity at second difference. The second difference ADF unit root test is presented in table 5.

Table 5. Result of ADF unit root test at second difference

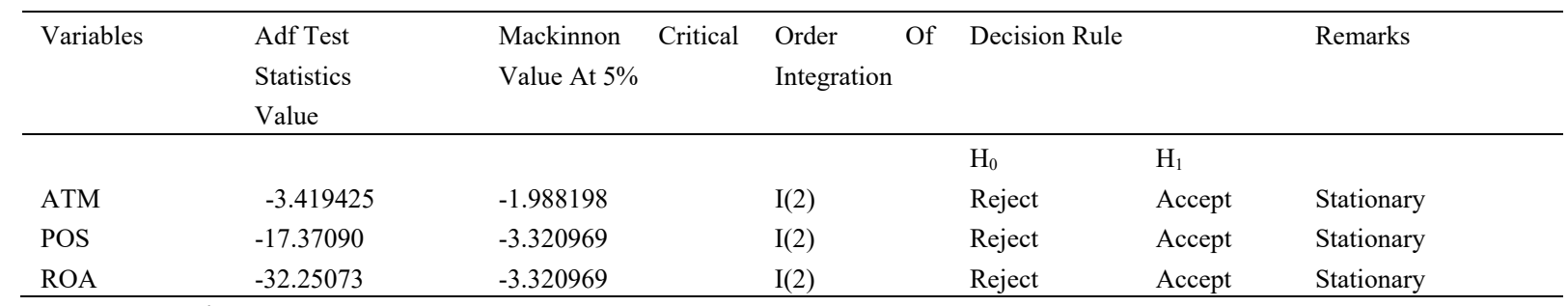

Source: Author's Computation

ADF unit root test in Table 5 shows that all the variables are stationary at second difference. In order to confirm the stationarity of the variables we proceed to carry out Phillips Perron (PP) Test of stationarity. 
Table 6. Result of PP unit root test at level

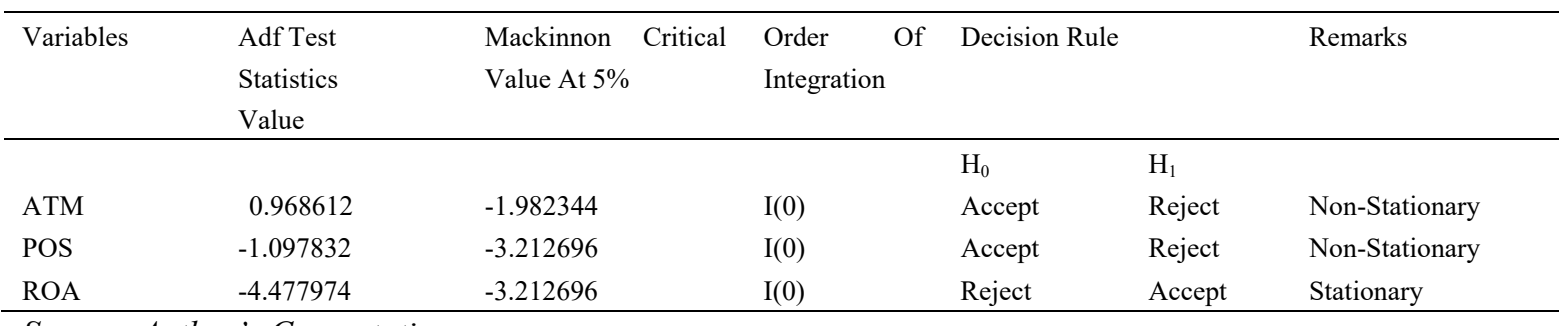

Source: Author's Computation

From table 6, the results of the test for stationarity of data at level i.e. before differencing, it could be deduced that all the variables have their PP test statistics value lesser than the Mackinnon critical value (at absolute term) and at $5 \%$ except ROA. Therefore, we fail to reject $\mathrm{H}_{0}$ and there is sufficient evidence to support $\mathrm{H}_{1}$ for ATM and POS.

To ensure the stationarity of data for variables found to be non-stationary at level, there is need to proceed to test for stationarity at first difference. The first difference PP unit root test is presented in table 4.3.5

Table 7. Result of PP unit root test at first difference

\begin{tabular}{|c|c|c|c|c|c|c|}
\hline Variables & $\begin{array}{l}\text { Adf Test } \\
\text { Statistics } \\
\text { Value } \\
\end{array}$ & $\begin{array}{l}\text { Mackinnon Critical } \\
\text { Value At 5\% }\end{array}$ & $\begin{array}{l}\text { Order Of } \\
\text { Integration }\end{array}$ & Decision Rule & & Remarks \\
\hline & & & & $\mathrm{H}_{0}$ & $\mathrm{H}_{1}$ & \\
\hline ATM & -1.327554 & -1.988198 & $\mathrm{I}(1)$ & Accept & Reject & Non-Stationary \\
\hline POS & -9.790308 & -3.259808 & $\mathrm{I}(1)$ & Reject & Accept & Stationary \\
\hline ROA & -10.76730 & -3.259808 & $\mathrm{I}(1)$ & Reject & Accept & Stationary \\
\hline
\end{tabular}

Source: Author's Computation.

From table 7 the results of the test for stationarity of data at level i.e. before differencing, it could be deduced that ATM have their ADF test statistics value lesser than the Mackinnon critical value (at absolute term) and at 5\% except POS and ROA. Therefore, we fail to reject $\mathrm{H}_{0}$ and there is sufficient evidence to support $\mathrm{H}_{1}$ for ATM.

To ensure the stationarity of data for variables found to be non-stationary at first difference, there is need to proceed to test for stationarity at second difference. The second difference PP unit root test is presented in table 8 .

Table 8. Result of PP unit root test at second difference

\begin{tabular}{|c|c|c|c|c|c|c|}
\hline \multirow[t]{3}{*}{ VARIABLES } & \multirow{2}{*}{$\begin{array}{l}\text { ADF TEST } \\
\text { STATISTICS } \\
\text { VALUE } \\
\end{array}$} & \multirow{2}{*}{$\begin{array}{l}\text { MACKINNON } \\
\text { CRITICAL VALUE } \\
\text { AT } 5 \%\end{array}$} & \multirow{2}{*}{$\begin{array}{l}\text { ORDER OF } \\
\text { INTEGRATI } \\
\text { ON }\end{array}$} & \multicolumn{2}{|c|}{ DECISION RULE } & \multirow[t]{2}{*}{ REMARKS } \\
\hline & & & & & & \\
\hline & & & & $\mathrm{H}_{0}$ & $\mathrm{H}_{1}$ & \\
\hline ATM & -3.419425 & -1.988198 & $\mathrm{I}(2)$ & Reject & Accept & Stationary \\
\hline POS & -45.16934 & -3.320969 & $\mathrm{I}(2)$ & Reject & Accept & Stationary \\
\hline ROA & -35.10149 & -3.320969 & $\mathrm{I}(2)$ & Reject & Accept & Stationary \\
\hline
\end{tabular}

Source: Author's Computation

PP unit root test in Table 4.3.6 shows that all the variables are stationary at second difference. The Augmented Dickey-Fuller (ADF) and Phillips Perron (PP) unit root test at second difference were applied in this regard and results above shows that the data are not affected by stationarity problem linked with lost time series data.

Due to the short period of the study, the short run relationship between the variables were ascertained as the number of observation would not allow for assessment of a long run relationship. This was achieved using the OLS technique and results summarized.

4.4 Test of Hypotheses

\subsubsection{Hypothesis One}

$\mathrm{H}_{0}$ : There is no significant relationship between ATM fraud and return on assets of deposit money banks in 
Nigeria.

$\mathrm{H}_{1}$ : There is a significant relationship between ATM fraud and return on assets of deposit money banks in Nigeria.

Table 9. OLS Regression of ATM fraud and return on assets of Nigerian DMB

\begin{tabular}{|c|c|c|c|c|}
\hline Variable & Coefficient & Std. Error & $\mathrm{t}$-Statistic & Prob. \\
\hline LOG(ATM) & -0.443832 & 0.364676 & -1.217058 & 0.2905 \\
\hline $\mathrm{C}$ & 9.056594 & 7.112495 & 1.273336 & 0.2719 \\
\hline R-squared & 0.270237 & Mean dependent var & & 0.407131 \\
\hline Adjusted R-squared & 0.087796 & S.D. dependent var & & 0.726035 \\
\hline S.E. of regression & 0.693431 & Akaike info criterion & & 2.366872 \\
\hline Sum squared resid & 1.923386 & Schwarz criterion & & 2.297458 \\
\hline Log likelihood & -5.100615 & Hannan-Quinn criter. & & 2.089004 \\
\hline F-statistic & 1.481231 & Durbin-Watson stat & & 1.516647 \\
\hline Prob(F-statistic) & 0.290476 & & & \\
\hline
\end{tabular}

Source: Computer output data using E-views 9.0.

The result in Table 9 shows that ATM Fraud is statistically insignificant at 5\% level of significance with p-value of 0.2905.This result agrees with previous study of Muoghalu, Okonkwo and Anawude (2018) who found a negative insignificant effect between electronic banking related fraud on deposit money banks financial performance in Nigeria for the period under review

Conclusion: The results of the OLS regression estimate in table 9 showed ATM coefficient of -0.443832 and probability of 0.2719 which is greater than 0.05 . Therefore, ATM Fraud has negative and insignificant effect on return on assets of deposit money banks in Nigeria for the period. Therefore, we fail to reject $\mathrm{H}_{0}$ and there is sufficient evidence to support $\mathrm{H}_{1}$, which states that ATM Fraud does not have a significant effect on return on assets of deposit money banks in Nigeria within the period of the study.

\subsubsection{Hypothesis Two}

$\mathrm{H}_{0}$ : There is no significant relationship between POS fraud and return on assets of deposit money banks in Nigeria.

$\mathrm{H}_{1}$ : There is significant relationship between POS fraud and return on assets of deposit money banks in Nigeria.

Table 10. OLS regression of POS fraud and return on assets of Nigerian DMB

\begin{tabular}{|c|c|c|c|c|}
\hline Variable & Coefficient & Std. Error & t-Statistic & Prob. \\
\hline LOG(POS) & -0.139591 & 0.233868 & -0.596880 & 0.5827 \\
\hline $\mathrm{C}$ & 2.959549 & 4.288040 & 0.690187 & 0.5280 \\
\hline R-squared & 0.081782 & \multicolumn{2}{|c|}{ Mean dependent var } & 0.407131 \\
\hline Adjusted R-squared & -0.147772 & \multicolumn{2}{|c|}{ S.D. dependent var } & 0.726035 \\
\hline S.E. of regression & 0.777831 & \multicolumn{2}{|c|}{ Akaike info criterion } & 2.596586 \\
\hline Sum squared resid & 2.420083 & \multicolumn{2}{|c|}{ Schwarz criterion } & 2.527173 \\
\hline Log likelihood & -5.789759 & \multicolumn{2}{|c|}{ Hannan-Quinn criter. } & 2.318718 \\
\hline F-statistic & 0.356266 & \multicolumn{2}{|c|}{ Durbin-Watson stat } & 1.386495 \\
\hline Prob(F-statistic) & 0.582730 & & & \\
\hline
\end{tabular}

Source: Computer output data using E-views 9.0.

The result in Table 10 shows that POS Fraud is statistically insignificant at 5\% level of significance with p-value of 0.5827 .

The Adjusted R-squared value of -0.147772 indicates that POS Fraud explained -14.7772 variations in return on assets of deposit money banks in Nigeria. The F-statistic of 0.356266 and p-value of 0.582730 shows that POS Fraud did not significantly influenced variations in return on assets of deposit money banks in Nigeria within the period of the study.

Conclusion: The results of the OLS regression estimate in table 10 showed POS coefficient of -0.139591 and probability of 0.582730 which is greater than 0.05 . Therefore, POS Fraud has negative and insignificant effect on 
return on assets of deposit money banks in Nigeria for the period. Therefore, we fail to reject $\mathrm{H}_{0}$ and there is sufficient evidence to support $\mathrm{H}_{1}$, which states that POS Fraud does not have a significant effect on return on assets of deposit money banks in Nigeria within the period of the study.

\subsection{Recommendations}

Based on the outcome of the findings, the following recommendations are suggested to stakeholders, which incude banks, government, investors and the general public for consideration so as to improve the deposit money banks operation and financial stability in general.

1. Government should evolve a good regulatory environment that will enable the banks to be more accountable and fraudulent activities to be easily detected.

2. Strengthening anti-fraud awareness campaigns: Deluge of e-fraud cases are perpetrated through phishing scams and instances of identity theft. It has been proving difficult for banks to easily identify perpetrators of this crime. Therefore, it behoves on them to designed and conceptualize a better approach towards detecting this malady and possible punishment. Nation-wide awareness campaign should be embarked upon to sensitize the general public concerning the modus operandi of this fraudsters.

\section{References}

Abdurasheed, A., Babaita, I. S., \& Yinusa, M. A. (2012). Fraud and its implication for bank performance in Nigeria. International Journal of Asian Social Science, 12(4), 382-387

Adeyomo, E. C. (2012). Impact of fraud on banks' performance in Nigeria. The Nigerian Academic Forum, 19(1).

Afzal, I. Z., Redvin, B., \& Jamaliah, S. (2017). E-commerce fraud: an investigation of familiarity, trust and awareness impact towards online fraud.

Agu, A. A. (2006). Electronic payment systems and tele-banking services in Nigeria. J. Internet Banking Comm, $11(3), 1-10$

Akindele, R. I. (2011). Fraud as a negative catalyst in the Nigerian banking industry Journal of Emerging Trends in Economics and management Sciences (JETEMS). Bank administration institute of America and First National bank of Chicago: Fraud prevention series. Benson and Edwards fraud prevention series (Volumes 1-11). B \& E publishers Lagos.

Alexis, O. R. (2001). Theories of fraud.

Alleyne, T. D., \& Howard, J. O. (2005). Finance and the sources of growth. Policy Research Working Paper Series 2057. The World Bank.

Cain, S. (1999). Fraud in the workplace. Orange County Business Journal, 22(16), 78-98.

CBN. (2003). An analysis of advance fee fraud on the internet, CBN Journal of Financial crime, 15(1), 71-81.

Dorminey, J., Fleming, A. S., Kranacher, M. J., \& Riley, A. R. (2012). The evolution of fraud theory. Issues in Accounting Education, 27(2), 555-579. https://doi.org/10.2308/iace-50131

Egungwu, E. O. (2005). An empirical assessment of the operational efficiency of electronic banking: Evidence of Nigerian banks. Review of Public Administration and Management, 1(2), 76-110.

Enoch, Y. S., John, A. K., \& Olumuyiwa, A. E. (2013). Mitigating Cyber Identity Fraud using Advanced Multi Anti-Phishing Technique. International Journal of Advanced Computer Science and Applications (IJACSA), 4(3), 156-164. Retrieved from http://thesai.org/Publications/ViewPaper?Volume $=4 \&$ Issue $=3 \&$ Code $=I J A C S A \& S e r i a l N o=25$

Enyi, E. I. (2007). The Current State of Cybercrime: An Inside Look at the changing Threat Landscape.

Gitau, E. W., \& Samson, N. G. (2016). Effect of financial fraud on the performance of commercial banks: a case study of tier 1 banks in Nakuru town, Kenya. International Journal of Economics, Commerce and Management, 4(20), 142-157.

Inaya, L., \& Isito, E. O. (2016). An empirical analysis of social impact of fraud on the Nigerian banking industry. Research Journal of Finance and Accounting, 7(4), 12-17.

Kanu, S. I., \& Okoroafor, E. O. (2013). The Nature, Extent and Economic Impact of Fraud on Bank Deposit in Nigeria. Interdisciplinary Journal of Contemporary Research in Business, 4(9), 253-264.

Kelvin, O. (2012). Mobile money for financial inclusion. Journal of Macro Finance, Africa, 4, 14.

Lucey, A. D. (2003). Fraud Prevention and Internal Control in the Nigerian Banking System. International 
Journal of Economics and Financial Issues, 6(3), 1172-1179.

Muoghalu, J. K., Okonkwo, V. I., \& Ananwude, C. A. (2018). Impact of e-banking on the profitability of banks in Nigeria. Research Journal of Finance and Accounting, 5(22), 53-63.

Muritala, T. A., Ijaiya, M. A., \& Adeniran, D. S. (2017). Fraud and bank performance nexus: Evidence from Nigeria using vector error correction model. Journal of Business Finance, 3(1), 21-29.

Mwabu, D. K. (2017). Factors influencing electronic fraud in the banking Industry in Kenya: A case of Kenya commercial bank Central region. An MSc presentation made at the department of Project Planning and Management of the university of Nairobi. Retrieved from http://erepository.uonbi.ac.ke/bitstream/handle/11295/60487/Mwabu_Factors\%20Influencing\%20Electroni c\%20Fraud\%20In\%20The\%20Banking\%20Industry\%20In\%20Kenya.pdf?sequence=3

Nwankwo, O. (2013). Implications of Fraud on Commercial Banks Performance in Nigeria. International Journal of Business and Management, 8(15), 144-150.

Olaoye, C. O., \& Dada, R. A. (2014). Analysis of Frauds in Banks: Nigeria's Experience. European Journal of Business and Management, 6(31), 90-99.

Osuagwu, P., \& Umeh, J. (2018). Rising wave of e-frauds puts economy at risk. Retrieved from https://www.vanguardngr.com/2018/06/rising-wave-e-frauds-puts-economy-risk/

Ovia, J. (2001). Internet Banking: practices and potentials in Nigeria, A paper presented at a seminar organized by the Institute of Chartered Accountants of Nigeria (ICAN) Lagos Sheraton Hotel \& Towers, Ikeja, (September 05).

Rezaee, Z. (2004). Causes, consequences and deterrence of financial statement fraud, Critical Perspective on Accounting.

Steven, A. (2002). Information System: The information of E-Business.

Taiwo, J. N., \& Agwu, M. E. (2017). The role of e-banking on operational efficiency of banks in Nigeria. Basic Research Journal of Business Management and Accounts, 6(1), 1-10.

Taiwo, J. N., Agwu, M. E., Babajide, A. A., Okafor, T. C., \& Isibor, A. A. (2016). Growth of bank frauds and the impact on the Nigerian banking industry. Journal of Business Management and Economics, 4(12), 1-10.

Tijani, J. A., \& Ilugbemi, A. O. (2015). Electronic payment channels in the Nigeria banking sector and its impacts on national development. Asian Economic and Financial Review, 5(3), 521-531. Retrieved from http://www.aessweb.com/journals/5002

Vinton, K. (2014). Data Breach Bulletin: Brazilian Banks Lose \$3.75 Billion Because of Boleto Malware. Retrieved

from https://www.forbes.com/sites/katevinton/2014/07/07/data-breach-bulletin-brazilian-banks-lose-3-75-billionbecause-of-boleto-malware/\#5668dea84397

\section{Copyrights}

Copyright for this article is retained by the author(s), with first publication rights granted to the journal.

This is an open-access article distributed under the terms and conditions of the Creative Commons Attribution license (http://creativecommons.org/licenses/by/4.0/). 